Rev. Tadeusz Zadykowicz Katolicki Uniwersytet Lubelski Jana Pawła II

\title{
The Ethics of Tourism: Determining the Fundamental Moral Issue, Part I
}

Many academic disciplines, including and relatively recently philosophical ethics and moral theology, are interested in the issue of tourism. Moral theology (theological ethics) strives to create (interpret) an existing system of norms according to which one can determine whether human activities in tourism are either good or evil. These activities are very complex. Therefore, theologians must first delineate the field of research and determine and prepare a set of issues to be studied. An ontology of tourism (defining the essence of tourism, the subjects and objects of touristic acts, the types of tourism, etc.) can serve as a point of departure for theological and moral reflections on tourism. Kairology and axiology are also general issues to consider. Placing the values (threats) of tourism within the context of contemporary signs of the time, which include the changing perception of the aims of tourism, is necessary. Specifically theologians must consider particular issues such as the personal, material, and functional interactions that are involved in planning and implementing touristic aims as well as the different types of travel.

Key words: tourism, travel, ethics, morality.

Considering the subject of tourism from an ethical, theological, and moral point of view is a relatively new endeavor. Certainly such considerations are not easy to find in older and even contemporary textbooks on ethics, theology, and morals. The first analyses of this issue did not appear until after the Second World War. At that time, the social sciences conducted these analyses; now, however, it is difficult to determine to which academic discipline or field of knowledge they belong. Interest in tourism within the humanities did not develop until 
Moral theology

the 1970s. More recently, this topic has not been discussed within the field of moral theology, but interest in the topic of tourism has grown and will continue to increase, which is evidenced by the fact that more and more publications, magazines, conferences, and research centers are addressing this issue.

As both the scope and scale of tourism respectively broaden and increase, and since a tourism is recognized as an example of postmodern man, ${ }^{1}$ various academic disciplines, including the humanities (philosophy, history, anthropology, theology, and semiotics), the social sciences (sociology, psychology, pedagogy, political science, and economics), the natural sciences (geography, ecology), the technical sciences (architecture, urban planning, and transport), and even the exact sciences (environmental protection) have analyzed this phenomenon. ${ }^{2}$ It is also evident in the proper methodology of research. Today's practical attitude toward science as such, however, is not conducive to a humanistic (and especially an ethical) approach. Such practical attitudes are conducive to a utilitarian approach (e.g., such as in economics, and at least some of its branches). However, tourism cannot be reduced simply to the statistics of touristic movement and the hotel industry's share in the national economy.

Consequently, an interdisciplinary approach to tourism is particularly valuable, since it makes it possible to present and examine the issue more fully. Sometimes, however, interdisciplinary approaches lead to chaos as exemplified in a lack of competence. Despite this danger, ethical, theological, and moral issues must be included in reflections on tourism. It is also important to note that the theological sciences have a different approach to this issue; for example, pastoral theology approaches the issue of tourism differently than moral theology. ${ }^{3}$

The aim of moral theology (theological ethics) is to create (interpret) an existing system of norms that are meant to guide the entire sphere of tourism. In light of these norms, it is possible to judge whether human activities in tourism are either good or bad. However, since these activities are extremely complex, it is first necessary to systematically create a group of issues, determine the scope of the research, and

1 See Z. Bauman, Ponowoczesne wzory osobowe, in idem, Dwa szkice o moralności ponowoczesnej, Warsaw 1994, pg. 30.

2 See J. Płocka, Turystyka - wybrane zagadnienia, Torun 2009, pg. 7.

3 For example, the Polish Bishop's Council for Migration, Tourism, and Pilgrimages wrote the document Vademecum duszpasterstwa turystycznego (11.23.2016), which presents a theological and pastoral point of view on tourism and speaks of some of the moral dangers of tourism in paragraph 3 . The document, however, focuses on pastoral ministry. 
state where such reflections fit in in the entire scheme of theological and moral issues. Once a field of research has been determined, then specific issues to be explored can likewise be established.

An ontology of tourism (defining its essence as well as the object and the subject of a tourist act, its relationship within tourism, the types of tourism, etc.) is the point of departure for theological and moral reflections on tourism. Kairology and axiology are also general issues to consider. It is also necessary to locate the values (threats) of tourism within the context of contemporary signs of the time. Specifically theologians must consider particular issues such as the personal, material, and functional interactions that are involved in planning and implementing touristic aims. To begin, it is necessary, however, to note that an ethical reflection on tourism is de facto different when compared to, for example, sociological or biological reflections on this issue.

\section{Types of Ethical Reflections on Tourism}

Not only many sciences study tourism from their respective perspectives, but even each field of discipline within the sciences has a variety of approaches to this phenomenon. This also applies to ethical, theological, and moral reflections on this sphere of human activity. There are as many ethics of tourism and ethics for tourism as their are concepts of the human person, since each ethical reflection necessarily relies on a particular understanding of anthropology. Existing studies reveal that there is great diversity in the way that different researchers evaluate and defend their evaluations of specific issues. They place different emphases on the problems that they investigate depending on their concepts of man. Consequently, they present various arguments in favor of or against human touristic activities. For this reason, in order to understand the moral judgments that a given field makes regarding man and his activities in the realm of tourism, it is first necessary to understand the specific anthropology that this field (or researcher) upholds as a condition for correct methodology.

Ethics of tourism extends beyond the professional ethics. For, if ethics for tourism were limited only to professional ethics, then such ethics would concern only regulations and norms that control the behavior of those who organize and promote tourism. "Ethics of tourism" also (and perhaps firstly) involves the tourist's moral judgment. While norms that regulate tourism are necessary, ethics for tourism cannot be reduced to the legal norms that regulate this sphere because legal norms consider only exterior activity and are usually minimalistic, 
Moral theology

whereas morality considers the inner sphere-the sphere of a person's intentions and motivations - and is, therefore, maximalist.

Creating a code of ethics is the simplest and most universal way in which individuals reflect ethically on tourism. In principle, these codes are created for specific types of professional groups. Because of this, ethics in tourism is typically reduced to professional ethics. Yet, as previously stated, ethics in tourism is more than just ethics applied to those who represent the tourism industry. Although it is tempting to create a catalogue of norms, duties, and even sanctions for tourists, this would only reduce ethics to the law. And, even the most specific codex would not be able to take into consideration the variety of situations that arise with regard to organizing and participating in touristic events. Nevertheless, ethicists have attempted to create such codes, ${ }^{4}$ even on an international level, ${ }^{5}$ which reflects the current-day obsession with codifying every area of life and the exaggerated belief that increasing legal regulations will prevent abuse, even in tourism. ${ }^{6}$

Some studies on ethics simply mention and assess examples of the kinds of situations that most typically occur with tour operators, travel agents on location, and a tour company, on the one hand, and with tourists and residents of tourist locations, on the other hand. An approach to ethics of tourism that considers only ethical codes is almost always negative because most codes focus almost exclusively on unethical behavior and neglect to consider compelling changes or norms. In other words, the only reason people are interested in ethical codes is to consider obvious examples of the conflicts that can arise between participants (tourists, residents of tourist locations, and those involved in providing tourism services: travel agents, hotels, tour guides, etc.). Some industries connected with tourism create lists

In Poland, some of the provisions contained in the Act on tourist services, which was issued on August 29, 1997 (as amended), or the Regulation of the Minister of the Economy and Work, which was issued on January 17, 2006 and concerns tour guides, are like this.

5 See Manila Declaration on World Tourism (1980) and On the Social Impact of Tourism (1997); Charter of Rights for Tourists, adopted under the auspices of the WTO in Sofia in 1985; the Cape Town Declaration on Responsible Tourism in Destinations), which was signed in 2002; and, most importantly, the Global Code of Ethics for Tourism, which was adopted by the World Tour Organization in 1999. The code of ethics that the International Guide Organization (OGO) prepared for companies that organize high-altitude expeditions (over 8,000 m) in the Himalayas is an example of a code of ethics that expresses the need to be socially responsible.

See M. Kazimierczak, Kodeksy etyczne szansą dla turystyki?, "Rocznik Naukowy Ido - Ruch dla Kultury" 6(2006), pgs. 14-15. 
of good practices and their own code of ethics for their own internal use. ${ }^{7}$ To stimulate the tourism industry to act ethically, individuals and entities also implement special programs that seek to promote reliability ${ }^{8}$ or a professional deontology that strives to create a desired ethos. J. Butcher established his own theory of moral tourism in 2003 based on this concept, which B. Ma further developed.

As within every type of ethics, tourism ethics relies on a specific anthropology and ultimately involves applying general ethical principles to specific situations that occur in this realm of human activity. The fundamental norm of Christian ethics is personalistic. ${ }^{9}$ In light of this norm, everything that violates the human person is considered negative. ${ }^{10}$ In Christian ethical reflections on tourism, the human conscience is taken into particular consideration, since it is the first witness of human acts as well as the realm where moral decisions are made. All of ethics in tourism, including all of the branches and the fields connected to it such as the protection of the natural environment in the development of tourism, business ethics, touristic enterprise, ethics in the hotel industry, property ethics, etc., should be based precisely on the internal criterion of the conscience and objective principles, both of which are essentially features of the personalistic principle. Theological and moral reflections on tourism serve not only as a response to the modern development of tourism, but also as "signs of the times," which undoubtedly show the changes that have taken place in how people perceive the very aims of tourism. This article will attempt to define the more fundamental ethical problems associated with tourism below.

7 In the hotel industry, for example. Por. J. Adamowicz, G. Wolak, Jak być hotelarzem? Cracow 2004, pgs. 13-14. For example, tourist entities use the Code of Conduct, which has been binding since October 20, 1999 and defines standards and rules of conduct between hoteliers and representatives of travel agencies. The International Hotel \& Restaurant Association (IHRH) and the Universal Federation of Travel Agents' Associations (UFTAA) prepared this document.

The Program "Hotel Fair Play," for example. This program is implemented in 5 environments: hotels, guesthouses, motels, conference centers, and wellness centers. The first edition of this program ended in December 2008, and three entities were each awarded the certificate of "Hotel Fair Play."

$9 \quad$ It proclaims the primacy of the human person in relation to things and to the community. Man is a value because of who he is, not because of what he has or what he does. To recognize this primacy is to theoretically and in practice accept the fact that the human person with his transcendent nature "is the source, the center, and the purpose of all economic and social life" (Gadium et Spes, 63).

10 Perhaps the most obvious (although not only) example of a violation of the personalistic principle is the use of people, especially sexually, in tourism. 
Moral theology

\section{Theological and Moral Reflections on Tourism} as a Response to the Signs of the Time

Moral theology's increasing interest in the issue of tourism is due to a number of contemporary phenomena, the most important of which is the increasing possibilities that have arisen in the field of tourism. These possibilities are due to economic development and the corresponding increases in individuals' income, which has made it possible for people to more easily access tourist services. ${ }^{11}$ In addition, over the years transportation has improved and become more accessible, thereby facilitating the movement of people. In turn, urbanization has increased people's appreciation for the natural environment. The development of the hotel industry, which is an important aspect of tourism, is also significant. ${ }^{12}$ All of these factors have made tourism and tourist activities a part of people's way of life..$^{13}$

The development of ethical reflections on tourism is connected with the fact that modern man has an increasing amount of free time, and one way that he spends this time is by engaging in tourism. Ethics in tourism cannot be categorized solely within the field of ethics of leisure because spending one's free time in touristic pursuits inevitably involves and necessitates the work of others. In this regard, ethics in tourism pertains equally to the ethics of leisure and to the ethics of labor. Moreover, how modern man uses his time is another issue to consider because he must choose what form of tourism he wishes to engage $\mathrm{in}^{14}$ as well as the complex motivations that underlie these activities. ${ }^{15}$ Moreover, new ways to promote novel forms of tourism and information as well as access to touristic equipment have influenced current forms of tourism and given rise to new forms.

From a moral and theological perspective, the phenomenon of tourism has a place in the broad context of contemporary phenomena and cultural tendencies. Although the proliferation of tourism is often

11 See A. Mazur, M. Bekta, Turystyka kwalifikowana a formy wypoczynku, in Turystyka i zdrowie, A. Mazur (ed.), Warsaw 2011, pg. 136.

12 See A. Woś, Rozwój hotelarstwa na świecie. Imponujace hotele świata, in Turystyka $i$ zdrowie..., pg. 105.

13 See Z. Krawczyk, O turystyce i rekreacji. Studia i szkice, Warsaw 2007, pg. 63.

14 See M. Bonneau, Czas w turystyce: “czas indywidualny” $i$ “czas spoteczny”, “Turyzm” 19(2009), nos. 1-2, pg. 16.

15 See A. Anszperger, Etyka zawodowa w turystyce, "Ekonomia i Prawo" 6(2010), pg. 459. Por. also: M. Kasperczyk et al.,Aspekty motywacyjno-emocjonalne uprawiania turystyki, "Prace Naukowe Akademii im. Jana Długosza w Częstochowie" 6(2005), pgs. 211-221. 
viewed as something positive, the reality is that it can be an effect of consumerism, hedonism, and man's disposition to want only to be entertained and have fun. The modern technicization of life means that man transfers these tendencies into the realm of tourism, and he is becoming increasingly satisfied with "artificial" attractions. The following contemporary tendencies also affect how man perceives tourism and realizes it: utilitarianism, permissiveness, moral relativism, situational ethics, and extreme subjectivity. What lies beneath all of these phenomena, which are the hallmarks of moral crises, is man's distorted concept and experience of freedom, which he treats as if it autonomously comes from his own power, which is confirmed in his pursuit of his own selfishness and often used against others.

Another sign of the times is the mentality of modern tourists who Bauman characterizes in the following way:

While on vacation, a tourist pays upfront for his freedom from moral obligations; before he travels, he purchases prophylactic measures that will ameliorate his pangs conscience, just like he purchases medicine to prevent sea- and airsickness before his trip. That which the tourist's real-life baggage does not contain (and the lack of which excuses him) is the onerous, crippling, and overwhelming joie de vivre and the moral responsibility that looms at large. ${ }^{16}$

Disputes about the very purpose of tourism are also undoubtedly signs of the times. Such disputes are more practical-rather than theological-in nature, and they concern tourist destinations more than academic institutions.

\section{Disputes Over the Aims of Tourism}

Many moral problems arise from how individuals understand tourism and its aims. This does not concern the objective aims of tourism, since these are unchanging, but rather tourists' changing preferences, which make it necessary for those in the tourist industry to constantly diversify what they offer. ${ }^{17}$ Rest is regarded as the objective aim of tourism. The need for rest, concern for one's health and beauty, as

$16 \quad$ Z. Bauman, Etyka ponowoczesna, Warsaw 1996.

17 Not only elements of nature and culture are "tourist attractions," but even slums, cemeteries, shopping malls, metropolitan centers (por. S. Bosiacki, P. Rydlewski, Wielkomiejskie centra i galerie handlowe jako miejsca rekreacji i atrakcje turystyczne, "Zeszyty Naukowe Wyższej Szkoły Handlu i Usług w Poznaniu" 2009, no. 16, pgs. 35-45), and industrial and post-industrial spaces (por. J. Sikora, A. Wartecka-Ważyńska, Turystyka przemysłowa i poprzemysłowa $w$ Polsce - stan obecny i możliwości rozwoju, ibid, pgs. 77-88). 
Moral theology

well as a person's curiosity about the world are inscribed in human nature. Therefore, individuals consider tourism a right that arises from the right to rest. Tourism separates a person from his everyday tasks, thereby allowing him to regain the proper distance from and perspective of them so that he can return to them re-invigorated. Since tourism enables a person to regain his physical and spiritual strength, it can be a means to improve fitness. In addition, tourism can promote health because it separates individuals from unhealthy environments and brings them to a place where there are no factors that are harmful to health.

Tourism not only strives to help individuals rest, it also has cognitive aims and is associated with broadly understood self-improvement. Tourism enables people to satisfy their curiosity about the world ${ }^{18}$ by enabling them to have personal contact with the natural, cultural, and social environments of the places they visit. Such environments contain a variety of attractions that create a particular impression. Moreover, tourism also has cognitive and educational roles; it provides people with the possibility to learn about the world and other cultures. The Global Code of Ethics for Tourism (hereafter abbreviated as the Global Code) states: "Tourism, the activity most frequently associated with rest and relaxation, sport and access to culture and nature, should be planned and practised as a privileged means of individual and collective fulfilment; when practised with a sufficiently open mind, it is an irreplaceable factor of self-education, mutual tolerance and for learning about the legitimate differences between peoples and cultures and their diversity." 19 The Global Code also indicates the role of tourism in establishing peace in the world and serving as a platform for dialogue, including religious dialogue. ${ }^{20}$

Objectively speaking, tourism has three functions: recreational and health-promoting, social and educational, as well as economical. ${ }^{21}$ Today, however, considerably more is attributed to these functions which is evident in the shift in tourism that has occurred from emphasizing the three S's (sea, sun, and sand) to the three E's (entertainment,

18

See A. Mazur, M. Bekta, Znaczenie współczesnego krajoznawstwa dla rozwoju turystyki kwalifikowanej, in Turystyka i zdrowie..., pg. 51.

19

20

21

Article2.1:http://ethics.unwto.org/en/content/global-code-ethics-tourism-article-2.

See M. Ostrowski, Dialog religijny $w$ turystyce, "Polonia Sacra" 16(2012), no. 2, pgs. 107-121.

See A. Mazur, M. Bekta, Znaczenie współczesnego krajoznawstwa dla rozwoju turystyki kwalifikowanej, in Turystyka i zdrowie..., pg. 52. Por. also: M. Olczyk, Moralne aspekty turystyki, "Teologia i Moralność” 2013 no. 1, pg. 220. 
excitement, and experience). ${ }^{22}$ In this sense, individuals today can choose from among many more kinds of tourism, many of which are morally questionable. For example, sex tourism, which is sometimes Moral theology outright pathological, ${ }^{23}$ can be called into moral question, along with many other kinds of tourism that entail various ethical dilemmas, including ethnic tourism, military tourism, event tourism, and thanatourism. ${ }^{24}$ Some aspects of science,${ }^{25}$ linguistic, ${ }^{26}$ and medical ${ }^{27}$ tourism raise questions about justice. Therefore, human touristic activity can be judged based on its type-whether the atmosphere of a tourist destination promotes safety and security, or whether it violates human rights and dignity. Moreover, many new aims and forms of tourism are promoted on Internet forums and blogs ${ }^{28}$ which consequently instill high expectations and desires that potential tourists feel must be met.

In our current day, tourism is treated not only as a social and cultural phenomenon, ${ }^{29}$ but also-on an increasingly universal level—as a source of economic benefit. The increasing role and rank of tourism in the economy spur ethical reflections on business ethics, ${ }^{30}$ which is a rather narrow approach to the issue. More important are the motives of both tourists and those who organize tourism. Interior motivation directs an individual to engage in activities that are valuable in and of themselves. On the other hand, it is possible for individuals to have

22 See K. Parzych, P. Czapliński, Etyka w zarzadzaniu przedsiębiorstwem turystycznym..., pg. 167.

See J. Poczta, I. Szebiotko, Seksturystyka - między turystyka kulturowa a patologiczna, "Turystyka Kulturowa" 2014, no. 4, pg. 16.

See S. Tanaś, Tanatoturystyka - kontrowersyjne oblicze turystyki kulturowej, "Peregrinus Cracoviensis" 2006, no. 17, pgs. 85-100.

See J. Kosiewicz, Protreptikos - zachęta do turystyki naukowej, "Folia turistica" 2011, no. 24, pgs. 59-77.

See J. Murrmann, Turystyka lingwistyczna rozpatrywana przez pryzmat danych wizualnych - o prawdziwym charakterze wakacyjnych kursów językowych na podstawie analizy fotografii. "Folia Turistica" 2016, no. 40, pgs. 27-45.

See K. Kowalska,Kontrowersyjne podróże turystyki medycznej, "Folia Turistica" 2016, no. 40, pgs. 71-84.

See I. Morozova, Blog podróżniczy jako przestrzeń dla kreowania i komunikowania wzorców podroży, "Folia Turistica" 2016, no. 40, pgs. 119-133.

See S. Owsianowska, Turystyka jako fenomen kulturowo-spoteczny, in Z. Dziubiński (ed.), Aksjologia turystyki, Warsaw 2006. 
Moral theology

a whole range of external motivations for, for example, their desire to be recognized. ${ }^{31}$

The arguments that ethics or moral theology present regarding the aims of tourism ultimately come down to making tourism friendly to man. ${ }^{32}$ In order for tourism to be friendly to man, people who provide or engage in all aspects of tourism must embrace and uphold moral principles in all situations that take place in the sphere of tourism. Within the context of the moral good or evil, ethics in tourism analyzes the behavior of three basic groups of people: tourists, residents of tourist areas, and "intermediaries," meaning employees of travel agencies, hotels, and travel guides ${ }^{33}$ Ethically approaching tourism by considering three simple categories according to the three aforementioned groups is a considerable over-simplification, since such ethics must consider the whole range of relationships that arise from tourism. The Ethical Code of Tourism distinguishes three basic groups in tourism: tourists—the local community; economic activity in tourism-the natural environment; and tourism-protecting cultural goods.

Significantly more relationships than the ones stated above exist. For example, Bonislawski points out the ethical conflict related to the variety of roles that people play and their value and good as aims of tourism. For example, if a businessman carries out his mission toward his guests (value), but neglects the good connected with fulfilling his role toward himself (family) and the firm, then his activity is unethical with regards to his family and his business..$^{34}$ An entrepreneur in tourism fulfills the following roles: 1 ) a member of a territorial community, 2) a person responsible for the life of his family, 3) an employer and a business owner, and 4) a member of the professional community. An employer is subsequently responsible for: 1) ensuring the livelihood of his employees, 2) the financial outcomes and development of the company (in relation to the economic system), 3) the quality of the services (that he provides to customers), and 4) suppliers and other

31 See Z. Ciekanowski, W. Zapalski, Rodzaje czynników motywacyjnych w organizacji, in Turystyka i zdrowie..., pg. 22.

32 See M. Ostrowski, Turystyka przyjazna człowiekowi, http://www.pastoralna.pl/ files/408\%20Turystyka\%20przyjazna\%20cz\%C5\%82owiekowi.pdf (Accessed: 10.30.2017).

33 See K. Przecławski, Wprowadzenie do filozofii turystyki, in Turystyka $w$ badaniach naukowych, R. Winiarski, W. Alejziak (ed.), Cracow - Rzeszow 2005, pgs. 50-59.

34 See M. Bonisławski, Kto i jak odpowiada za warunkowanie jakości odczuć turysty - gościa? "Annales. Etyka w życiu gospodarczym" 9(2006), no. 2, pg. 141. 
partners. ${ }^{35}$ Generally speaking, however, "ethical" tourism involves conscious and responsible behavior in all interpersonal relations and in natural, social, and cultural environments, as well as in economic relations. ${ }^{36}$ These issues require a more detailed discussion.

$* * *$

Although obvious, the topic of tourism ethics itself immediately forces an individual to specify which kind of ethics is being considered. Various types of reflections on the good and bad of human acts in this and every other area of life and human action exist. Each of these reflections is based on a particular anthropology, which ethics should not obscure. The variety of ethical, theological, and moral reflections are manifested in the multiplicity of sources from which general principles are derived as a means to judge specific activities. This variety is also evident in the way that one issue is given precedence over another and the degree to which data is used from different scientific disciplines.

An entire range of disciplines related to tourism ethics exists, including professional ethics of those who work in the tourism industry, work ethics, ethics of free time, and business ethics. Ethical reflection should include tourism. It is insufficient, however, to create a code of ethics or set of good practices, since this kind of approach always lacks a true foundation. What is necessary is an ethics of tourism based on an integrated view of the human person, from whose nature general ethical principles can be derived and serve as a tool for evaluating specific issues. Such ethics should lie somewhere between the minimalism of legal norms and the maximalism to which the human person is called. This is possible when an ethics of tourism based on a personalism that upholds the primacy of the person is developed. This kind of ethics, however, cannot be immune to contemporary phenomena, including changes in the way that modern man approaches tourism, which should be interpreted according to the "signs of the times."

$35 \quad$ See ibid, pg. 147.

36 See A. Sancewicz-Kliś, Turystyka odpowiedzialna w wymiarze lokalnym i globalnym, in Turystyka i zdrowie..., pg. 97. 


\section{O ETYKĘ W TURYSTYCE. PRÓBA USTALENIA ZASADNICZEJ PROBLEMATYKI MORALNEJ (I)}

Fenomen turystyki jest przedmiotem zainteresowania wielu dyscyplin naukowych; od stosunkowo niedawna także etyki filozoficznej i teologii moralnej. Teologia moralna (etyka teologiczna) próbuje stworzyć (odczytać istniejący) system norm, w świetle których można oceniać działania człowieka w sferze turystyki jako dobre bądź złe. Działania te są bardzo złożone. Dlatego eksploracja poszczególnych zagadnień domaga się najpierw zakreślenia pola badawczego, sporządzenia grupy problemów badawczych. Punktem wyjścia refleksji teologicznomoralnej nad turystyką jest swego rodzaju ontologia turystyki (określenie jej istoty, przedmiotu i podmiotu aktu turystycznego, rodzajów turystyki, itp.). Do zagadnień ogólnych należy także kairologia i aksjologia. Chodzi o umieszczenie wartości (zagrożeń) turystyki w kontekście współczesnych znaków czasu, do których należy także zmiana w postrzeganiu celów turystyki. Zagadnienia szczegółowe obejmują problematykę szeroko rozumianych relacji osobowych, rzeczowych i funkcjonalnych, jakie tworzą się w związku z planowaniem i realizacją celów turystycznych oraz rodzajem podejmowanej podróży.

Słowa kluczowe: turystyka, podróże, etyka, moralność.

\section{Bibliography:}

1. Adamowicz J., Wolak G., Jak być hotelarzem? Cracow 2004.

2. Anszperger A., Etyka zawodowa w turystyce, "Ekonomia i Prawo" 6(2010), pgs. 459-467.

3. Bauman Z., Dwa szkice o moralności ponowoczesnej, Warsaw 1994.

4. Bauman Z., Etyka ponowoczesna, Warsaw 1996.

5. Bonisławski M., Kto i jak odpowiada za warunkowanie jakości odczuć turysty - gościa? "Annales. Etyka w życiu gospodarczym" 9(2006), no. 2, pgs. 141-152.

6. Bonneau M., Czas w turystyce: "czas indywidualny" $i$ "czas społeczny," "Turyzm" 19(2009), nos. 1-2, pgs. 13-16.

7. Bosiacki S., Rydlewski P., Wielkomiejskie centra i galerie handlowe jako miejsca rekreacji i atrakcje turystyczne, "Zeszyty Naukowe Wyższej Szkoły Handlu i Usług w Poznaniu" 2009, no. 16, pgs. 35-45.

8. Buczkowska K., Malchrowicz-Mośko E., Etyczne dylematy turystyki kulturowej, "Turystyka Kulturowa" 2012, no. 12, pgs. 42-55.

9. Ciekanowski Z., Zapalski W., Rodzaje czynników motywacyjnych w organizacji, in Turystyka i zdrowie, A. Mazur (ed.), Warsaw 2011, pgs. 19-39.

10. Kasperczyk M. et al., Aspekty motywacyjno-emocjonalne uprawiania turystyki, "Prace Naukowe Akademii im. Jana Długosza w Częstochowie" 6(2005), pgs. 211-221. 
11. Kazimierczak M., Kodeksy etyczne szansa dla turystyki? "Rocznik Naukowy Ido-Ruch dla Kultury" 6(2006), pgs. 11-20.

12. Kosiewicz J., Protreptikos - zachęta do turystyki naukowej, "Folia Turistica" 2011, no. 24, pgs. 59-77.

13. Kowalska K., Kontrowersyjne podróże turystyki medycznej, "Folia Turistica" 2016, no. 40, pgs. 71-84.

14. Krawczyk Z., O turystyce i rekreacji. Studia i szkice, Warsaw 2007.

15. Mazur A., Bekta M., Turystyka kwalifikowana a formy wypoczynku, in Turystyka i zdrowie... pgs. 135-141.

16. Mazur A., Bekta M., Znaczenie współczesnego krajoznawstwa dla rozwoju turystyki kwalifikowanej, in Turystyka i zdrowie..., pgs. 51-58.

17. Morozova I., Blog podrożniczy jako przestrzeń dla kreowania i komunikowania wzorców podroży. "Folia Turistica" 2016, no. 40, pgs. 119-133.

18. Murrmann J., Turystyka lingwistyczna rozpatrywana przez pryzmat danych wizualnych - o prawdziwym charakterze wakacyjnych kursów językowych na podstawie analizy fotografii. "Folia Turistica" 2016, no. 40, pgs. 27-45.

19. Olczyk M., Moralne aspekty turystyki, "Teologia i Moralność" 2013 no. 1, pgs. 211-231.

20. Ostrowski M., Dialog religijny $w$ turystyce, "Polonia Sacra" 16(2012), no. 2, pgs. 107-121.

21. Ostrowski M., Turystyka przyjazna człowiekowi, http://www.pastoralna. pl/files/408\%20Turystyka\%20przyjazna\%20cz\%C5\%82owiekowi.pdf (Accessed: 10.30.2017).

22. Owsianowska S., Turystyka jako fenomen kulturowo-spoteczny, in Z. Dziubiński (ed.), Aksjologia turystyki, Warsaw 2006.

23. Parzych K., Czapliński P., Etyka w zarządzaniu przedsiębiorstwem turystycznym..., pg. 167.

24. Płocka J., Turystyka - wybrane zagadnienia, Torun 2009.

25. Poczta J., Szebiotko I., Seksturystyka - między turystyka kulturowa a patologiczna, "Turystyka Kulturowa" 2014, no. 4, pgs. 16-27.

26. Przecławski K., Wprowadzenie do filozofii turystyki, in Turystyka w badaniach naukowych, R. Winiarski, W. Alejziak (eds.), Cracow-Rzeszow 2005, pgs. 50-59.

27. Polish Bishop's Council for Migration, Tourism, and Pilgrimages, Vademecum Duszpasterstwa Turystycznego (11.23.2016).

28. Sancewicz-Kliś A., Turystyka odpowiedzialna $w$ wymiarze lokalnym i globalnym, in Turystyka i zdrowie..., pgs. 95-104.

29. Sikora J., Wartecka-Ważyńska A., Turystyka przemystowa i poprzemystowa $w$ Polsce - stan obecny $i$ możliwości rozwoju, "Zeszyty Naukowe Wyższej Szkoły Handlu i Usług w Poznaniu" 2009, no.16, pgs. 77-88.

30. Szalczyk A., Etyka biznesu w turystyce. "Zeszyty Naukowe Wyższej Szkoły Handlu i Usług w Poznaniu” no. 16, pgs. 105-114.

31. Tanaś S., Tanatoturystyka - kontrowersyjne oblicze turystyki kulturowej, "Peregrinus Cracoviensis" 2006, no. 17, pgs. 85-100.

32. World Tourism Organization, Global Code of Ethics for Tourism, 1999.

33. Woś A., Rozwój hotelarstwa na świecie. Imponujace hotele świata, in Turystyka $i$ zdrowie..., pgs. 105-126. 